\title{
RESIDU PESTISIDA GOLONGAN ORGANOFOSFAT KOMODITAS BUAH CABAI MERAH (Capsicum annuum $L$.) PADA BERBAGAI LAMA PENYIMPANAN
}

\author{
I G A Surya Utami Dewi ${ }^{* *}$, I Gede Mahardika ${ }^{2)}$, Made Antara ${ }^{3)}$ \\ ${ }^{1)}$ Magister Ilmu Lingkungan, Universitas Udayana \\ ${ }^{2)}$ Fakultas Peternakan, Universitas Udayana \\ ${ }^{3}$ Fakultas Pertanian, Universitas Udayana \\ *Email: agex_surya@yahoo.co.id
}

\begin{abstract}
In order to control pests and diseases in red chili plants, farmers use pesticides was over as impact leaving residue in the chili. The purpose of this study was to determine type, dose and frequency of pesticides used by the farmers, as well as to determine the organophospate residual in chili on different storage times. This study was conducted in two phases namely survey to 10 respondent farmers in Baturiti district, Tabanan regency used questioner and treatment pilot study used different storage time from 0,1 and 3 days samples took from Apuan Village, Baturiti, Tabanan. Class of organophosphate pesticide residue analysis conducted in Denpasar Branch Police Forensic Laboratory. The results showed dominant pesticides used was organophosphates profenofos (curacron) $60 \%$ and klorpirifos (kaliandra) $20 \%$. Dose pesticides used was $>40$ $\mathrm{ml}$ (> 4 bottle cover volume $10 \mathrm{ml}$ ) and $>40$ gram ( $>4$ spoon) for tank volume 17 liter and also $>30 \mathrm{ml}(>3$ bottle cover volume $10 \mathrm{ml}$ ) and $>30$ gram (>3 spoon) for tank volume 14 liter. Frequency of pesticides used by farmers on 1 plant season was $90 \%$ more than 12 times and the other $10 \%$ used frequency $10-12$ times. Farmers do not comply dose and frequency with the pesticides used regulations. Analysis result showed that the treatment effect of different storage time is not real to organophosphate pesticide residues groupon red pepper. The average residues detected are indicating a trend with residue storage profenofos on day 0,1 and day 3 for $1,20 \mathrm{mg} / \mathrm{kg}, 2,70 \mathrm{mg} / \mathrm{kg}$ and $1,37 \mathrm{mg} / \mathrm{kg}$ and the amount of chlorpyrifos residues on the storage day 0 , day 1 and day 3 is $0,0027 \mathrm{mg} / \mathrm{kg}, 0,0039 \mathrm{mg} / \mathrm{kg}$ and $0,0021 \mathrm{mg} / \mathrm{kg}$. Profenofos and chlorpyrifos residue content is still below the Maximum Residue Limit (MRL) under the provisions of MRL profenofos on red pepper, which is $5 \mathrm{mg} / \mathrm{kg}$ and chlorpyrifos, which is $0,5 \mathrm{mg} / \mathrm{kg}$.
\end{abstract}

Keywords: Pesticides Residue; Organophosphates; Profenofos; Chlorpyrifos

\section{PENDAHULUAN}

Dewasa ini tanaman cabai menjadi komoditi sayuran penting di Indonesia, memiliki nilai ekonomis yang tinggi, dan seiring dengan pertambahan jumlah penduduk maka permintaan akan cabai merah akan meningkat tajam (Yusniawati, 2008). Meningkatnya permintaan masyarakat pada komoditas cabai di Bali dapat dilihat dari tingkat produksi cabai pada tahun 2013 yang mengalami peningkatan $20,23 \%$ dari tahun sebelumnya, dimana produksi sayuran cabai mencapai 35.856 ton dari tahun sebelumnya yang hanya mencapai 29.824 ton (BPS Bali, 2013). Namun kendalanya dalam budidaya cabai yaitu rentan akan serangan hama dan penyakit. Serangan hama dan penyakit pada tanaman dapat menyebabkan terjadinya penurunan hasil produksi serta gagal panen. Pestisida merupakan salah satu alternatif utama yang dipakai petani dalam menanggulangi serangan hama dan penyakit karena dianggap lebih efektif dibandingkan dengan penanggulangan secara biologis dan fisik. Rata-rata peningkatan total konsumsi pestisida per tahun mencapai 6,33\%, namun pada kenyataanya di lapangan diperkirakan dapat mencapai lebih dari 10-20 \% (Djunaedy, 2009).

Penggunaan pestisida pada tanaman cabai paling sering ditemukan kandungan residunya. Kandungan residu yang ditemukan yaitu pestisida golongan organofosfat jenis propenofos residunya melebihi batas maksimum residu profenofos pada tanaman cabai yaitu $5 \mathrm{mg} / \mathrm{kg}$. Hal ini dikarenakan adanya petani yang sering mengambil langkah praktis, mereka langsung menyemprot dengan pestisida tanpa memperhatikan nilai ambang ekonomi hama, dosis anjuran dan jenis pestisida (Afriyanto, 2008). Berdasarkan hasil penelitian Soemirat (2003) residu insektisida golongan organofosfat ditemukan pada berbagai jenis sayuran seperti bawang merah dengan konsentrasi 0,565-1,167 mg/kg, kentang 0,125-4,333 $\mathrm{mg} / \mathrm{kg}$. Sedangkan cabai dan wortel mengandung profenofos $0,11 \mathrm{mg} / \mathrm{kg}$, detakmetrin $7,73 \mathrm{mg} / \mathrm{kg}$, klorpirifos $2,18 \mathrm{mg} / \mathrm{kg}$, tulubenzuron $2,89 \mathrm{mg} / \mathrm{kg}$, dan permetrin $1,80 \mathrm{mg} / \mathrm{kg}$.

Struktur kimia dan cara kerja organofosfat berhubungan erat dengan gas syaraf. Organofosfat 
dapat menurunkan populasi serangga dengan cepat, persistensinya di lingkungan sedang sehingga organofosfat secara bertahap dapat menggantikan organoklorin. Organofosfat merupakan insektisida yang paling toksik diantara jenis pestisida lainnya dan sering menyebabkan keracunan pada manusia. Termakan hanya dalam jumlah sedikit saja dapat menyebabkan kematian, tetapi diperlukan beberapa milligram untuk dapat menyebabkan kematian pada orang dewasa (Zulkarnain, 2010).

Residu pestisida pada cabai dapat berasal dari hasil penyemprotan pada tanaman. Residu pestisida terdapat pada semua tubuh tanaman seperti batang, daun, buah, dan juga akar. Walaupun sudah dicuci atau dimasak residu pestisida ini masih terdapat pada bahan makanan. Oleh karena itu maka dibuatlah suatu percobaan untuk mengetahui pengaruh lama penyimpanan terhadap residu pestisida golongan organofosfat pada komoditas buah cabai merah. Percobaan yang dilakukan juga diperkuat dengan data wawancara mendalam yang dilakukan kepada petani untuk mengetahui aplikasi jenis dosis dan frekuensi penggunaan pestisida oleh petani di Kecamatan Baturiti, Tabanan.

\section{METODOLOGI}

Penelitian dilaksanakan pada bulan Oktober sampai Desember 2015. Penelitian ini terdiri dari 2 tahapan yaitu penelitian tahap 1 dengan wawancara menggunakan kuisioner kepada petani di Kecamatan Baturiti, Kabupaten Tabanan dengan mengambil 10 orang responden secara acak masing-masing di Desa Apuan, Desa Bangli, Desa Angsri, Desa Baturiti, Desa Perean dan Desa Candikuning. Variabel penelitian tahap 1 yaitu pengamatan mengenai jenis, dosis serta frekuensi penggunaan pestisida pada petani cabai merah. Instrumen yang digunakan dengan prosedur kerja melakukan wawancara langsung sekaligus mencatat jawaban responden. Hasil wawancara selanjutnya ditabulasi.

Penelitian tahap 2 menggunakan rancangan acak lengkap (RAL) dengan perlakuan yang dicobakan yaitu : CO : Lama penyimpanan 0 hari (panen); C1 : Lama penyimpanan 1 hari dan C3 : Lama penyimpanan 3 hari. Setiap unit perlakuan diulang sebanyak 3 kali sehingga secara keseluruhan terdapat 9 petak percobaan. Sampel buah cabai merah yang digunakan dalam penelitian diambil di Desa Apuan, Kecamatan Baturiti, Kabupaten Tabanan. Variabel penelitian tahap 2 yaitu kandungan residu pestisida golongan organofosfat jenis profenofos dan klorpirifos pada buah cabai merah dengan perlakuan lama penyimpanan. Untuk mengetahui kandungan residu pestisida golongan organofosfat pada buah cabai merah sampel buah cabai merah dianalisis di Laboratorium Forensik
Polri Cabang Denpasar dengan gas kromatografi (GCMS).

\section{HASIL DAN PEMBAHASAN}

\subsection{Aplikasi Jenis, Dosis dan Frekuensi Penggunaan Pestisida Oleh Petani Cabai Merah di Kecamatan Baturiti, Tabanan}

Data kuisioner menunjukkan merk dagang insektisida yang paling banyak digunakan sejumlah $60 \%$ yaitu Curacron 500 EC, $20 \%$ merk Kaliandra 482 EC dan sisanya $20 \%$ menggunakan insektisida dengan merk yang beragam diantaranya yaitu Winder, Decis, Bima, Matador, Metindo dan Sanval (Tabel 1).

Curacron dengan bahan aktif profenofos memiliki gugus brom dan klor yang dikhawatirkan akan memiliki bahaya yang sama dengan organoklor. Toksisitas pestisida dapat diketahui dari nilai LD 50 oral dan dermal yaitu dosis yang diberikan dalam makanan hewan-hewan percobaan yang menyebabkan $50 \%$ dari hewan-hewan tersebut mati. Nilai LD 50 profenofos yaitu LD 50 (tikus) sekitar $358 \mathrm{mg} / \mathrm{kg}$; LD 50 dermal (kelinci) dengan kelas toksisitas beracun sedang (IPCS, 1996). Sifat profenofos sebagai golongan organofosfat yaitu tidak menimbulkan kontaminasi terhadap lingkungan untuk jangka waktu yang lama, lebih toksik terhadap hewan-hewan bertulang belakang jika dibandingkan dengan organoklorin, mempunyai cara kerja menghambat fungsi enzim cholinesterase dan berefek toksik bila tertelan (Afriyanto, 2008). Umur residu dari profenofos ini tidak berlangsung lama sehingga peracunan kronis terhadap lingkungan cenderung tidak terjadi karena faktor-faktor lingkungan mudah menguraikan senyawa-senyawa profenofos menjadi komponen yang tidak beracun. Walaupun demikian senyawa ini merupakan racun akut sehingga dalam penggunaannya faktor-faktor keamanan sangat perlu diperhatikan. Pestisida

Tabel 1. Penggunaan Jenis Pestisida Oleh Petani Cabai Merah di Kecamatan Baturiti Tabanan

\begin{tabular}{llc}
\hline No & Jenis Penggunaan Pestisida & Jumlah (\%) \\
\hline 1 & Jenis pestisida yang digunakan & \\
& A. Pestisida organik/biopestisida & 0 \\
B. Pestisida anorganik & 100 \\
2 & Jenis pestisida yang paling banyak digunakan & 0 \\
A. Herbisida & 10 \\
B. Fungisida & 90 \\
C. Insektisida & 0 \\
D. Lain-lain & 60 \\
Merek dagang insektisida yang paling banyak digunakan & \\
A. Curacron & 0 \\
B. Diazinon & 20 \\
C. Kaliandra & 20 \\
D. Lain-lain &
\end{tabular}


curacron merupakan pestisida yang memiliki izin terdaftar dan beredar untuk pertanian dan kehutanan tahun 2016 di Indonesia.

Kaliandra dengan bahan aktif klorpirifos memiliki 3 gugus klor yang juga dikhawatirkan dampak negatifnya. Nilai LD 50 klorpirifos yaitu LD 50 oral (tikus) sebesar 135-163 mg/kg; LD 50 dermal (tikus) $>2.000 \mathrm{mg} / \mathrm{kg}$ dengan kriteria toksisitas beracun sedang (IPCS, 1996). Umur residu dari klorpirifos ini sama dengan profenofos yaitu tidak berlangsung lama sehingga peracunan kronis terhadap lingkungan cenderung tidak terjadi karena faktor-faktor lingkungan mudah menguraikan senyawa-senyawa klorpirifos menjadi komponen yang tidak beracun.

Penggunaan pestisida yang dilakukan oleh petani dalam hasil wawancara $100 \%$ melebihi dari dosis pemakaian pestisida yang dianjurkan (Tabel 2). Dalam penggunaan pestisida sebagian besar petani tidak membaca aturan pakai yang tertera dalam kemasan pestisida. Pengukuran dosis pestisida yang dipakai petani adalah dengan menggunakan tutup botol pestisida atau menggunakan takaran sendok makan. Pencampuran pestisida yang dilakukan yaitu $>40 \mathrm{ml}$ (> 4 tutup kemasan ukuran $10 \mathrm{ml}$ ) dan $>40$ gram (> 4 sendok makan) untuk tanki ukuran 17 liter serta $>30 \mathrm{ml}$ (> 3 tutup kemasan ukuran 10 ml) dan $>30$ gram ( $>3$ sendok makan) untuk tanki ukuran 14 liter. Hal ini tidak sesuai dosis berdasarkan kriteria dosis dan ukuran tanki. Apabila pestisida tersebut tidak dapat membunuh hama, maka petani akan meningkatkan dosis pemakaiannya. Pada saat menjelang panen dosis yang dipakai bisa meningkat 2 kali dari dosis pemakaian biasanya.

Petani di Kecamatan Baturiti melakukan penyemprotan pestisida tidak sesuai dengan anjuran dari Dinas Pertanian yang menganjurkan penyemprotan dilakukan hanya menggunakan satu jenis bahan pestisida. Petani di daerah ini melaksanakan penyemprotan dengan mencampur insektisida, fungisida, pupuk dan bahan perekat pada saat penyemprotan dengan alasan untuk menghemat waktu dan tenaga. Frekuensi penyemprotan pestisida oleh petani pada tanaman cabai di Kecamatan Baturiti dalam 1 musim tanam $90 \%$ lebih dari 12 kali dan sisanya $10 \%$ dalam rentangan frekuensi 10-12 kali. Penyemprotan dilakukan pada saat tanaman cabai berumur 1 minggu sampai dengan cabai siap panen. Waktu awal penanaman cabai sampai dengan siap panen rata-rata 105 hari. Frekuensi penyemprotan yang dilakukan berbedabeda, pada saat musim hujan penyemprotan pestisida dilakukan lebih intensif yaitu 2 sampai 3 hari sekali karena lebih rentan akan serangan hama dan penyakit. Sedangkan pada musim kemarau penyemprotan pestisida dilakukan 7 hari sekali. Penyemprotan pestisida dilakukan pada pagi atau sore hari. Interval penyemprotan yang pendek tentu saja tidak efisien dan dapat menimbulkan dampak negatif dari residu yang ditimbulkannya.

Tabel 2. Dosis dan Frekuensi Penggunaan Pestisida Oleh Petani Cabai Merah di Kecamatan Baturiti Tabanan

\begin{tabular}{llc}
\hline No & Dosis dan Frekuensi Penggunaan Pestisida & Jumlah (\%) \\
\hline $1 \quad \begin{array}{l}\text { Dosis yang digunakan melebihi atau kurang dari dosis } \\
\text { yang dianjurkan }\end{array}$ & 100 \\
A. Lebih dari dosis yang dianjurkan & 0 \\
B. Kurang dari dosis yang dianjurkan & \\
$2 \quad$ Frekuensi penyemprotan pestisida pada tanaman & \\
dalam 1 musim tanam & 0 \\
A. 5-10 kali & 10 \\
B. 10-12 kali & 90 \\
C. Lebih dari 12 kali & 20 \\
Waktu penyemprotan pestisida terakhir sebelum panen & \\
A. 1-2 hari menjelang panen & 80 \\
B. 3-7 hari menjelang panen & 0 \\
C. Lebih dari 1 minggu menjelang panen &
\end{tabular}

Waktu penyemprotan pestisida terakhir yang dilakukan sebelum panen menunjukkan hasil $80 \%$ dilakukan pada 3 sampai 7 hari menjelang panen dan sisanya $20 \% 1$ sampai 2 hari menjelang panen. Rekomendasi penyemprotan terakhir insektisida berbahan aktif klorpirifos minimal 15 hari sebelum panen (Amoako, 2012), sementara aplikasi terakhir profenofos yang dianjurkan 14 hari sebelum panen (Irie, 2007). Secara teori makin lama waktu aplikasi insektisida golongan organofosfat sebelum panen maka kadar residunya juga semakin rendah, hal tersebut mencerminkan lebih besarnya proses degradasi residu yang terjadi pada buah cabai akibat pengaruh suhu dan cahaya matahari yang lebih tinggi. Insektisida golongan organofosfat tidak tahan terhadap suhu tinggi dan cahaya matahari, khususnya spektrum ultraviolet (Syahbirin et al., 2001). Penelitian Triani (2005), juga melaporkan bahwa semakin dekat waktu antara penyemprotan terakhir dengan waktu panen, semakin banyak residu insektisida yang ada.

\subsection{Residu Pestisida Golongan Organofosfat Pada Buah Cabai Merah dengan Perlakuan Lama Penyimpanan}

Hasil analisis residu pestisida golongan organofosfat jenis profenofos dan klorpirifos dengan perlakuan lama penyimpanan pada buah cabai merah menunjukkan hasil yang tidak berbeda nyata. Hasil analisis residu disajikan pada Tabel 3.

Kandungan residu profenofos dan klorpirifos pada cabai merah menunjukkan adanya trend berdasarkan perlakuan lama penyimpanan pestisida yang diuji cobakan. Rata-rata residu profenofos yang terdeteksi yaitu $1,20 \mathrm{mg} / \mathrm{kg}$ sampai $2,70 \mathrm{mg} / \mathrm{kg}$ sedangkan rata-rata residu klorpirifos yang terdeteksi 
yaitu $0,0021 \mathrm{mg} / \mathrm{kg}$ sampai $0,0039 \mathrm{mg} / \mathrm{kg}$. Kurva kadar residu profenofos dan klorpirifos disajikan pada gambar 2 dan 3.

Tabel 3. Hasil Analisis Residu Profenofos dan Klorpirifos

\begin{tabular}{lccc}
\hline Jenis & \multicolumn{3}{c}{ Perlakuan } \\
\cline { 2 - 4 } Pestisida & $\begin{array}{c}\text { Hari ke-0 } \\
\text { (Panen) }\end{array}$ & $\begin{array}{c}\text { Hari ke-1 } \\
\text { (Penyimpanan } \\
1 \text { hari) }\end{array}$ & $\begin{array}{c}\text { Hari ke-3 } \\
\text { (Penyimpanan } \\
\text { 3 hari) }\end{array}$ \\
\hline $\begin{array}{l}\text { Profenofos } \\
\text { Klorpirifos }\end{array}$ & $0,0027 \mathrm{a}$ & $0,0039 \mathrm{a}$ & $\begin{array}{c}1,37 \mathrm{a} \\
0,0021 \mathrm{a}\end{array}$ \\
\hline
\end{tabular}

Keterangan: Nilai rata-rata yang diikuti oleh huruf yang sama pada kolom yang sama, menunjukkan pengaruh yang tidak berbeda nyata pada uji Duncan.

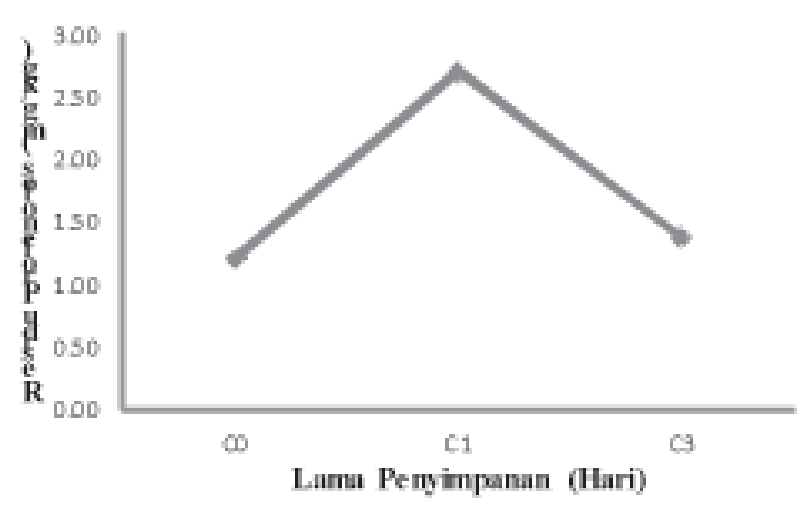

Gambar 1. Kurva Residu Profenofos Buah Cabai Merah CO: Residu lama penyimpanan 0 hari; $\mathrm{C} 1$ : Residu lama penyimpanan 1 hari; C3: Residu lama penyimpanan 3 hari

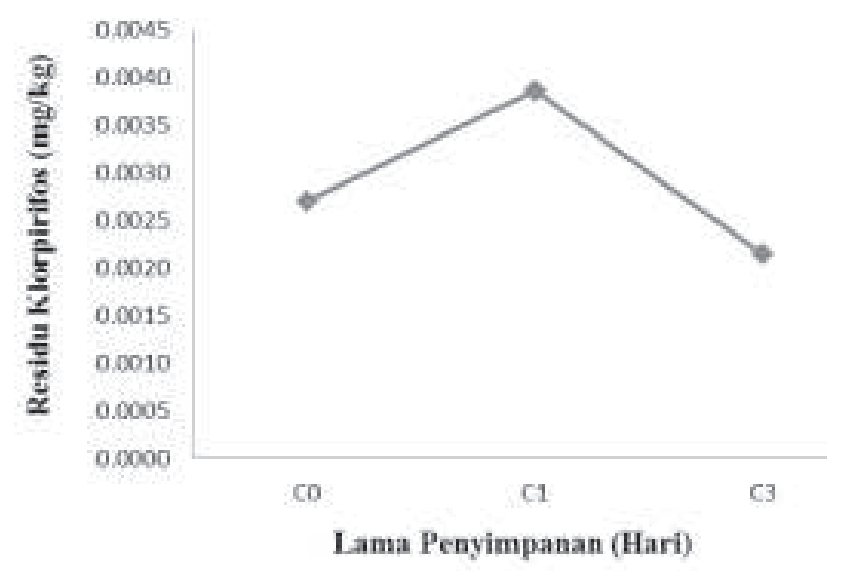

Gambar 2. Kurva Residu Klorpirifos Cabai Merah CO: Residu lama penyimpanan 0 hari; $\mathrm{C} 1$ : Residu lama penyimpanan 1 hari; C3: Residu lama penyimpanan 3 hari

Hasil residu profenofos lebih tinggi dari residu klorpirifos disebabkan oleh penggunaan insektisida dengan bahan aktif klorfirifos di Desa Apuan masih lebih rendah penggunaan dosisnya dibandingkan dengan penggunaan insektisida dengan bahan aktif profenofos. Residu pestisida profenofos terdeteksi lebih tinggi juga disebabkan karena tekanan uap profenofos sebesar $1,87 \times 10^{-5}$ Pa bersifat tidak volatil, sehingga bahan aktifnya cenderung untuk terdeposit dipermukaan bahan (Suardiana, 2014).

Gambar kurva 2 dan 3 menunjukkan kadar residu rata-rata profenofos pada hari ke-0 yang terdeteksi yaitu $1,20 \mathrm{mg} / \mathrm{kg}$, setelah disimpan 1 hari rata-rata residu meningkat menjadi $2,70 \mathrm{mg} / \mathrm{kg}$ dan setelah disimpan kembali selama 3 hari rata-rata residu turun menjadi $1,37 \mathrm{mg} / \mathrm{kg}$. Sedangkan kadar residu rata-rata klorpirifos pada hari ke-0 yaitu 0,0027 $\mathrm{mg} / \mathrm{kg}$, setelah disimpan selama 1 hari rata-rata residu naik menjadi $0,0039 \mathrm{mg} / \mathrm{kg}$ dan disimpan selama 3 hari rata-rata residu menurun menjadi $0,0021 \mathrm{mg} / \mathrm{kg}$.

Kandungan residu profenofos dan klorpirifos pada hari ke-0 lebih rendah dari perlakuan penyimpanan selama 1 hari disebabkan karena pada saat hari ke0 kadar air yang terkandung dalam sampel cabai merah cenderung tinggi dalam kondisi sampel masih segar. Pada kondisi kadar air tinggi residu menurun karena sebagian besar residu berikatan dengan air membentuk persenyawaan.

Setelah disimpan selama 1 hari didalam karung berongga (perlakuan sama dengan penyimpanan yang dilakukan petani/pedagang) residu profenofos dan klorpirifos meningkat karena kadar airnya menurun dan berat tanaman cabai mengalami penyusutan, inilah yang menyebabkan residu pestisida terkonsentrasi sehingga terjadi peningkatan kadar residu.

Pada perlakuan penyimpanan sampel cabai selama 3 hari, residu profenofos dan klorpirifos ratarata menurun dari perlakuan penyimpanan selama 1 hari. Penelitian (Chairul et al, 2007) menyebutkan bahwa penyimpanan cabai merah pada suhu $5^{\circ} \mathrm{C}$ selama 7 hari dapat menurunkan kandungan residu insektisida. Hal ini disebabkan karena senyawa profenofos dan klorpirifos mempunyai waktu paruh yang relatif singkat sehingga dengan dilakukannya penyimpanan selama 3 hari sudah mampu menurunkan kandungan residu pestisida pada buah cabai. Penurunan residu juga disebabkan karena pestisida golongan organofosfat mudah terdegradasi dan mudah menguap. Degradasi untuk semua jenis pestisida rata-rata $>80 \%$ dalam 10 hari setelah aplikasi (Zhang et al, 2007).

Atmawidjaja (2004) juga menyebutkan pestisida golongan organofosfat adalah pestisida yang tidak memerlukan waktu lama untuk mengalami penguapan. Pestisida yang menguap ke udara akan terurai karena pengaruh suhu, kelembaban dan sinar matahari khususnya sinar ultra violet. Penguraian bahan pestisida tersebut tidak terjadi seketika itu juga, melainkan sedikit demi sedikit. Perubahan kimia yang terjadi pada residu organofosfat juga dapat dipengaruhi oleh faktor panas, kelembaban, radiasi, 
enzim dari tanaman atau mikroorganisme tanaman. Pestisida golongan organofosfat umumnya mudah terurai oleh faktor-faktor tersebut karena itu residu yang terdeteksi rendah atau tidak terdapat sebagai residu dalam tanaman (Spear, 1991).

Kandungan residu profenofos dan klorpirifos masih dibawah Batas Maksimum Residu (BMR) pestisida dengan ketentuan BMR profenofos pada cabai merah yaitu $5 \mathrm{mg} / \mathrm{kg}$ dan klorpirifos yaitu 0,5 $\mathrm{mg} / \mathrm{kg}$. Kandungan residu pestisida organofosfat yang rendah pada buah cabai disebabkan oleh faktor curah hujan rata-rata daerah penelitian serta faktor karakteristik buah cabai merah.

Pada daerah penelitian pengambilan sampel di Desa Apuan, Kecamatan Baturiti, Kabupaten Tabanan memiliki curah hujan rata-rata mencapai $1800 \mathrm{~mm} /$ tahun yang tergolong sangat tinggi. Pestisida organofosfat larut dalam air sehingga mudah hilang dalam pencucian (Alegantina et al., 2005). Klorpirifos hanya melekat pada permukaan daun maupun buah sehingga kemungkinan terbasuh air hujan sangat tinggi. Hal ini dijelaskan pula pada hasil penelitian Zhang et al (2007) menunjukkan bahwa hujan merupakan penyebab utama hilangnya pestisida. Sejalan dengan hal tersebut Srikandi (2010) menjelaskan bahwa residu permukaan dapat menghilang karena pembilasan dan hidrolisis. Dalam waktu 1-2 jam setelah tanaman diperlakukan dengan pestisida kemungkinan besar $40 \%$ deposit telah hilang karena pencucian jika terjadi hujan, sisanya terurai oleh sinar ultra violet. Faktor lain yang menyebabkan residu yang terdeteksi masih dibawah BMR yaitu karena karakteristik tanaman yang permukaannya mempunyai malam (wax), sukar dibasahi, sehingga absorpsinya lebih sukar dan deposit pestisidanya sedikit. Cabai merah mempunyai permukaan licin, pestisida yang menempel pada kulit buah lebih sukar terabsorpsi sehingga deposit pestisida sedikit (Amvrazi, 2011).

Walaupun hasil residu pestisida dalam buah cabai merah masih berada dibawah BMR, tidak menutup kemungkinan seseorang untuk mengalami gangguan kesehatan jika terpapar terus menerus. Organofosfat memiliki waktu paruh di dalam tubuh selama 10-12 hari, yang kemudian akan diekresikan lewat urine (Marbun et al., 2015). Residu insektisida organofosfat yang terdapat pada sayuran masuk kedalam tubuh manusia melalui mulut, maka dapat memberikan pengaruh terhadap kesehatan manusia. Dampak terhadap konsumen umumnya berbentuk keracunan kronis yang tidak langsung dirasakan. Namun, dalam waktu lama bisa menimbulkan gangguan. Gejala keracunan ini baru kelihatan setelah beberapa bulan atau tahun kemudian (Djojosumarto, 2008).

\section{SIMPULAN DAN SARAN}

\subsection{Simpulan}

Berdasarkan hasil penelitian dan pembahasan dapat disimpulkan beberapa hal yaitu:

1. Pestisida dominan yang digunakan petani cabai merah di Kecamatan Baturiti Tabanan adalah insektisida golongan organofosfat dengan jenis profenofos (curacron) $60 \%$ dan klorpirifos (kaliandra) $20 \%$. Dosis dan frekuensi penggunaan pestisida yang digunakan petani cabai merah di Kecamatan, Baturiti, Tabanan tidak sesuai dengan aturan/ketentuan pemakaian pestisida.

2. Tidak ada perbedaan yang nyata dari kandungan residu pestisida golongan organofosfat pada komoditas buah cabai merah di Desa Apuan, Baturiti Tabanan yang disimpan selama 3 hari.

\subsection{Saran}

Adapun saran yang diajukan dalam penyususan tesis ini yaitu sebagai berikut.

1. Perlu dilakukan kegiatan penyuluhan dan monitoring dari pemerintah kepada petani mengenai penggunaan pestisida yang bijaksana sesuai dengan anjuran/aturan.

2. Perlu dilakukan pengamatan pada parameter kadar air, suhu, kelembaban dalam penelitian pengaruh residu pestisida terhadap lama penyimpanan untuk mendapatkan data penelitian yang lebih akurat.

3. Perlu dilakukan penelitian lanjutan mengenai residu pestisida golongan organofosfat dengan perlakuan rentangan lama penyimpanan lebih panjang untuk melihat pengaruhnya terhadap kandungan residu pestisida.

4. Perlu dilakukan penelitian residu pestisida bahan aktif lain selain organofosfat untuk melihat jenis residu pestisida dominan yang terdeteksi di lapangan.

5. Perlu adanya penelitian-penelitian mengenai bahan alam/tanaman yang dapat dipakai mendegradasi pengaruh residu pestisida terhadap lingkungan sehingga pencemaran lingkungan akibat residu pestisida dapat dikurangi.

6. Perlu dilakukan penelitian-penelitian mengenai biopestisida sehingga dapat digunakan sebagai alternatif pestisida ramah lingkungan pengganti pestisida kimia.

\section{DAFTAR PUSTAKA}

Afriyanto. 2008. "Kajian Keracunan Pestisida Pada Petani Penyemprot Cabe di Desa Candi Kecamatan Bandungan Kabupaten Semarang" (tesis).Semarang: Universitas Diponegoro. 
Alegantina, S., Raini, M., Lastri. 2005. Penelitian Kandungan Organofosfat Dalam Tomat dan Selada yang Beredar di Beberapa Jenis Pasar di DKI Jakarta. Media Litbang Kesehatan Volume XV Nomor I.

Amoako P.K.,Kumah P. and Appiah F. 2010. Pesticides Usage In Cabbage (Brassica olearacea) Cultivation In The Ejisu-Juaben Municipality Of The Ashanti Region Of Ghana. International Journal Of Research And Chemistry And Environment. Vol 2 Issue 3 July 2012 (26-31).

Amvrazi, EG. 2011. The Impacts Of Pesticides Exposure. M. Stoytcheva (Ed). Fate Of Pesticide Residues on Raw Agricultural Crops after Postharvest Storage and Food Processing to Edible Portions, Pesticides-Formulations, Effects, Fate.576-588. Rijeka: Intech.

Atmawidjaja., Tjahjono., Rudyanto. 2004. Pengaruh Perlakuan Terhadap Kadar Residu Pestisida Metidation Pada Tomat. [cited 5 Maret 2015]. Available from: URL: http://acta.fa.itb.ac.id.

BPS Provinsi Bali. 2013. Bali Dalam Angka 2013. Denpasar: Badan Pusat Statistik Provinsi Bali

Chairul, S. M. dan . N. Kuswadi. 2007. Penurunan Kandungan Residu Insektisida Dimetoat dalam Cabai Merah (Capsicum annum L.) Akibat Iradiasi Gamma. JFN 1(1):23-30.

Djojosumarto, P. 2008. Teknik Aplikasi Pestisida Pertanian. Yogyakarta: Kansius.

Djunaedy, A. 2009. Biopestisida Sebagai Pengendali Organisme Pengganggu Tanaman (OPT) Yang Ramah Lingkungan. Embryo Vol 6 No 1. ISSN 0216-0188.

IPCS, 1996. Pesticide residues in food-1991: Joint FAO/WHO Meeting on Pesticide Residues Evaluations 1991. Part II. Toxicology. Geneva: World Health Organization.

Irie, M. 2007. Pesticide Residues in Food. Report of the JMPR 2007, FAO Plant Production and Protection Paper, 191, pp 210. pages 1357,144.

Marbun, Lulu Hotdina.,Nurmaini.,Taufik Ashar. 2015. Analisis Kadar Residu Pestisida Organofosfat Pada Sayuran Serta Tingkat Perilaku Konsumen Terhadap Sayuran yang
Beredar di Pasar Tradisional Pringgan Kecamatan Medan Baru Tahun 2015. Medan: Fakultas Kesehatan Masyarakat Universitas Sumatera Utara.

Soemirat. 2003. Analisis Residu Pestisida Pada Sayuran. Jurnal Pertanian Vol 45 (1), 10-14.

Spear, Robert. 1991. Recognized and Posible exposure to Pesticides dalam Handbook of Pesticide Toxicology, vol. I, 245- 255.

Srikandi. 2010. "Hubungan Antara Tingkat Residu Pestisida dan Komunitas Biota Tanah pada Lahan Padi Sawah"(tesis). Bogor: Institut Teknologi Bogor.

Suardiana, P. P. 2014. "Analisis Residu Pestisida Organofosfat Dalam Sayuran Dari Daerah Pertanian Kintamani Bangli”(tesis). Denpasar: Universitas Udayana.

Syahbirin, G., Purnama, H., Prijono, D. 2001. Residu Pestisida pada Tiga Jenis Buah Impor. Buletin Kimia (2001) 1, 113-118. [cited 1 April 2016]. Available from: URL:http://repository.ipb.ac.id/ bitstream/handle/123456789/9790/ Gustini_Syahbirin\%20_Residu_pestisida.pdf?sequence=1.

Triani, I, G, A, L. 2005. "Residu Insektisida Sidazinon pada Kacang Panjang (Vigna sinensis) yang Dihasilkan di Kabupaten Tabanan" (Tesis). Denpasar: Program Magister Ilmu Lingkungan Universitas Udayana.

Yusniwati. 2008. Studi Regenerasi Beberapa Genotipe Cabai (Capsicum annum L.) untuk Rekayasa Genetika. Padang: Direktorat Jenderal Pendidikan Tinggi Departemen Pendidikan Nasional, Pp 4-5.Vol 20.

Zhang, Z.Y.,Liu, X., Yu, X.,Zhang, C., Hong, X. 2007. Pesticide Residue In Spring Cabbage (Brassica Oleacea L.Var.Capitata) Grown In Open Field. Food Conf. 18 (6): 723-730.

Zulkarnain, I. 2010. Aplikasi Pestisida dan Analisa Residu Pestisida Golongan Organofosfat pada Beras di Kecamatan Portibi Kabupaten Padang Lawas Utara. (Serial Online). [cited 10 Maret 2015]. Available from: URL:http:// repository.usu.ac.id/bitstream/123456789/16894/ 5/Chapter\%20I.pdf. 